\title{
OUD-CHRISTELIJKE EPIGRAPHIE,
}

DOOR

- Dr. F. PIJPGR.

Bestudeering van de Oud.Cbristelijke opschriften is in meer dan ón opzicht van belang. Ten eerste worden de oudste gedenkstukken der Christelïke letterkunde er op merkwaardige wijze door toegelicht. Ten tweede bezitten zij de grootste beteekenis voor de toelichting en verklaring van hetgeen er aan andere gedenkstukken van het vroegste Christelijke verleden in muurschilderingen en beeldhouwwerken is overgebleven. De nog bestaande opschriften zijn uitsluitend grafschriften. Voor de kennis van hetgeen er onder de oudste Christenen omging in de harten, zijn ze daarom van te meer waarde. $\mathrm{Zij}$ geven toch de gevoelens weder, waaraan onze eerste geloofs-genooten begeerd hebben in blijvenden vorm uitdrukking te geven, dikwijls in treffende omstandigheden, kinderen bij het graf hunner ouders, de man bij het graf zijner vrouw, vaders en moeders bij de laatste rustplaats van rolwassen zonen of dochters.

Nog heden ten dage uiten zich de bewoners van Italië gaarne in aandoenlïke bewoordingen bij de graven hunner dooden. Een bezoek aan een kerkhof, bïr. aan de openbare begraafplaats bij "St. Laurentius buiten de muren" te Rome, is voldoende om hiervan de overtuiging te schenken. 
Met de oudste Christelijke roorzaten van het geslacht dat thans Italië bevolkt, is het niet anders geweest.

Waar worden Oud-Christelijke opschriften aangetroffen? $\mathrm{Zij}$ bevinden zich over Italië en andere landen verspreid. Een groot aantal daarvan wordt te $\operatorname{Rom} \theta$ aangetroffen. De Rossi gewaagde in 1861 van een getal van 11000 OudChristelijke opschriften te Rome 1). En sedert zijn er nog vele aan den dag gekomen. Voor een deel worden zij nog gelezen op de plaatsen in de katakomben waaraan zij oorspronkelijk zijn aangebracht. Voor een deel zän zij door de stad verspreid, in de kerken, musea en elders. Een aantal van de belangrïkste zijn tentoongesteld in het "Christelïk museum", verbonden aan St.-Jan-van-het Lateraan. Het prachtige pauselijke paleis, dat bij die eerwaardige kerk behoort, is nl. tot museum ingericht. In eenige open galerijen hangen de Oud-Christelijke opschriften aan den wand. Men kan ze dus bezien in het volle daglicht. Ze zijn blootgesteld aan de lucht, maar beschut voor den regen. De kern der verzameling wordt gevormd door de gedagteekende opschriften. Daarvan hangen er 71 (van het $j .238$ tot het $j .557)^{2}$ ). Verder zijn er een aantal bijeengebracht, waarop in het bijzonder Oud-Christelijke symbolen voorkomen, enz. Voorzoover dit mogelijk was is de dagteekening en de plaats van herkomst aangewezen. Deze rangschikking is van $D_{\theta}$ Rossi ${ }^{3}$ ). Oitmuntende photographieën van de wanden dezer galerijen, waarop men dus talrijke inscripties bijeenvindt en gemakkelijk naast elkander kan raadplegen, zijn opgenomen in het werk van Roller 4); geheel volledig zijn ze te vinden in het groote werk van O. Marucchi, "I monumenti del Museo cristiano Pio-Lateranensi" (Milaan, 1910 fol.). Verder worden

1) I. B. de Rossi, in de Praefatio, p. XVII* voor zijne: Inscriptiones christianae vrbis Romae, septimo saecvlo antiqviores, Rom. 1857-1861.

2) K. Baedeker, Italie centrale, Rome, Leipz. 1904, p. 311.

3) Baedeker, l. c., p. 310.

4) Th. Roller, Les catacombes de Rome, histoire de l'art et des croyances religieuses pendant les premiers siècles du christianisme, Paris, s. a., Yol. I, PI. X, XI, XII, XX, XXII, XXXI, XXXII. 
nog honderden Oud-Christelïke opschriften in Zuid-Frankrïk en in de Rj̈nstreken aangetroffen. Het aantal opschriften dat zich bevindt op de Oud-Christelijke sarkophagen, to Rowe en elders in Italië, ook in Z. Frankrïk bewaard, is niet groot.

Welke gedrukte verzamelingen bestaan er van zulke Oud-Christelijke opschriften? Voor Karel den Groote heeft niemand zulk een verzameling vervaardigd. Een of andere leerling van Alcuïnus schïnt de verzameling bjjeengebracht te hebben die in een codex te Einsiedeln bewaard bleef. Christelijke „epigrammata" nemen een derde van het geheele werk in, maar grafschriften zijn het niet ${ }^{1}$ ). Verder bevatten eenige verzamelingen uit ongeveer denzelfden tijd bloemlezingen van grafschriften in dichtvorm. De namen die onder deze grafschriften gestaan moeten hebben, en de dagteekeningen, werden weggelaten. Blijkbaar was het den vervaardigers van deze bloemlezingen er slechts om to doen voorbeelden bijeen te brengen, waarnaar zij nieuwe grafschriften konden opstellen 2). Voornamelijk drie HSS. van zulke verzamelingen komen hier in aanmerking, een HS. uit Heidelberg, nu in het Vatikaan, door Gruter opgenomen in zijne "Opschriften" ${ }^{3}$, een HS. van de XIde eeuw nit Klosterneuburg, van geringen omvang en beteekenis, welks inhoud omstreeks de 8ste eeuw te Rome moet zijn bijeengebracht 4), een HS. te Verdun uit de $X^{\text {de }}$ eeuw, bevattende 31 opschriften in dichtrorm, omstreeks de 8ste eeuw te Rome in kerken en katakomben afgeschreven. Dit laatste HS. wijkt in zooverre van de overige af, dat hier de dagteekening der inscripties niet wordt weggelaten, en de plaats waar zij zijn aangetroffen, nauwkeurig vermeld wordt 5). Hierbij zou eigenlïk nog een

1) De Rossi, 1. 1., Praef., p. VI*.

2) De Rossi, 1.l., p. VII:

3) Inscriptiones antiquae totius orbis Romani, industr. J. Gruteri, recens. cura J. G. Graevii, Amst. 1707, fol., p. MCLXUI-MCLXXVII. Zie De Rossi, 1. l., p. VII".

4) De Rossi, ib., p. VIII:.

5) De Rossi, ib., p. IX' seq. 
vierde HS. behooren, waarvan echter niet bekend is, waar het zich thans bevindt; het is dat waaruit Scaliger eenige inscripties opteekende op het laatste blad van zijn exem-

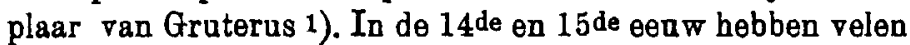
verzamelingen van oude inscripties aangelegd, zooals Poggius van Florence, Felix Felicianus, Dalmatius Berardencus, Laurentius Pehem, Hartmannus Schedel. Zij verzamelden echter hoofdzakelijk heidensche opschriften; de weinige Christelijke zijn onder de heidensche dooreengemengd 2). Petrus Sabinus was de eenige in dien tijd, die eene verzameling Christelïke inscripties bijeenbracht ; een HS. daarvan bevindt zich in de bibliotheek van S. Marco te Venetiö; het bevat echter uitsluitend opschriften uit eene zeer late periode ${ }^{3}$ ).

De wetenschappelijke studie der inscripties deed een grooten stap roorwaarts in de XVIde eeuw; thans eerst werden er met de vereischte nauwkeurigheid afschriften van gemaakt, door Martinus Smetius, Albertus Pighius, Joannes Metellus, Antonius Augustinus on Achilles Statius 4). Het werk van den eerste bestaat in druk; het berat slechts weinig Christelijke opschriften 5). Ook de werken der anderen, in HS. overgeleverd, behelzen voor het meerendeel heidensche opschriften. Pighius heeft nog 18 inscriptiën van Christelijken oorsprong bijeengebracht, de overigen geen of bïna geen ${ }^{6}$ ). Aldus Manutius jun. heeft een zeer groot aantal opschriften verzameld, die in eene reeks $\operatorname{van}$ HSS der Vatikaansche bibliotheek bewaard gebleven zïn; ook vele van Christelïken oorsprong, ontleend aan de kerken van Rome, inzonderheìd ook aan de steenen vloeren daarran (maar zeer weinige aan de katakomben) \%. Alles te zamen genomen leveren de HSS.

1) De Rossi, ib., p. $\mathrm{XI}^{*}$

2) De Rossi, l.1., p. XI* seq.

3) De Rossi, ib., p. XII* seq.

4) De Rossi, ib., p. XIV:

5) De Rossi, ib., p. XV:

6) De Rossi, 1.1., p. XIV* seq.

7) Dө Rossi, 1. 1., p. XVII". 
en boeken, in het voorafgaande besproken, op verre na geen 1000 Christeljke inscripties op, terwïl er zeker 11000 bestaan. De oorzaak ligt hierin, dat de katakomben in vergetelheid verzonken zijn 1). Door de wederontdekking der katakomben in $1578 \mathrm{kwam}$ er weldra in dezen eene zeer groote verandering. Niet zoo snel als men wellicht verwachten zou. De Nederlanders Joannes Macarius bïv. en Philippus Winghius maakten wel teekeningen van de wandschilderingen in de katakomben, maar schreven daar onder den grond geen of zoo goed als geen inscripties af, wat Winghius bijv. jijverig deed ten opzichte van bejdensche inscripties boven den grond ${ }^{2}$ ). Bosio is de eerste geweest die in grooten getale grafschriften uit de katakomben op volledige en nauwkeurige wijze heeft afgebeeld en beschreven ${ }^{3}$ ). Anderen hebben zijn werk roortgezet, zij het op niet even roortreffelijke wijze, bijv. Boldetti ${ }^{4}$ ). Een belangrijk aantal Oud-Christelïke inscripties zijn op fraaie wijze afgebeeld in het prachtwerk van Perret $\left.{ }^{5}\right) .0 p$ duurzamen, wetenschappelïken grondslag is de studie dezer inscripties eerst gevestigd door bet schitterende, ongeërenaarde werk van I. B. de Rossi, „De Christelïke opscbriften der stad Rome" 6). Het eerste deel is uitsluitend gewijd aan gedagteekende inscripties; 1376 daarvan, alle uit de eөrste zes eөuwen, boofdzakelijk uit de Christelïke begraafplaatsen te Rome, worden or in besproken. Het tweede behelst verzamelingen van Christelijke opschriften die bewaard gebleven zijn in de boven besproken Middeleeuwsche HSS. Ongeveer gelīktijdig met De Rossi heeft Le Blant in een drietal kloeke kwartijnen de oude Christelijke opschriften van Franschen

1) De Rossi, 1. l., p. XVII* seq.

2) Rossi, l. I, p. XVIIr seq.

3) Ant. Bosio, Roma sotterranea, Rom. 1632, fol.

4) Boldetti, Osservazioni sopra i cimeteri dei S.S. Martiri ed antichi cristiani di Roma, Rom. 1720, 2 roll., fol.

5) L. Perret, Les catacombes de Rome, Par. 1851, fol., in vol. V.

6) I. B. de Rossi, Inscriptiones christianae orbis Romae septimo sascolo antiquiores, Rom. 1857-1861, 2 voll. 
bodem op voortreffelijke wijze afgebeeld en beschreven ${ }^{1}$ ). $\mathrm{Di \theta}$ in de Rïnstreken zïn uitgegeven door Kraus ${ }^{2}$ ).

Een rijk materiaal is dus aanwezig. Over welke hulpmiddelen beschikt men om het op eene vruchtdragende wijze to bestudeeren? Bestaat er een geschikt leerboek der Christelïke epigraphie? Een goed leerboek der algemeene Latijnsche epigraphie is dat van (agnat ${ }^{3}$ ). Doch dit handelt alleen over opschriften van heidenschen oorsprong, en aan grafschriften is slechts een klein deel van het werk gewijd (p. 244-257). Het kan uitnemend dienen om den aard van beidensche grafschriften te leeren kennen, inzonderheid om deze te leeren onderscheiden van Christelïke. Ook worden zekere woordvormen, verkortingen en dergelïke die Christelijke en heidensche grafschriften met elkander gemeen kunnen hebben, er door opgehelderd. Verder gaan de diensten die het voor ons doel bewïzen kan, niet.

De Rossi heeft aan zijn groote werk over de inscripties eene leerzame "praefatio" laten voorafgaan. Zij licht den lezer in omtrent de verzamelingen van zulke inscripties die vroeger bestaan hebben. Hierop heeft hij uitroerige "Prolegomena" laten rolgen (p. I-cIvI). Zij bepalen zich hoofdzakelïk tot de chronologie en wäzen aan hoe $\mathrm{De}$ Rossi te werk gaat met de roorhanden gegevens om de dagteekening der behandelde inscripties zoo juist mogelïk vast to stellen. In het werk zelf bespreekt hï de 1374 gedagteekende opschriften in chronologische orde en analytisch. Een schat ran wetenswardigheden is in deze

1) Edm. Le Blant, Inscriptions chrétiennes de la Gaule, antérieures au VIII siecle, Par. 1856-1865, 2 tom.; dezelfde, Nouveau recueil d'inscriptions chrétiennes de la Gaule, anterioures au VIII's siècle, Par. 1892.

2) F. X. Kraus, Die christlichen Inschriften der Rheinlande, Freib. i. B., 1890-1894, 2 Teile. Aan deze opschriften is een studie gewijd door E. L. Smit, Het oudste christendom in de Rijnlanden, verschenen in de Kerkhistorische opstellen van het gezelschap S.S.S., 's-Gravenh. 1914, Nieuwe Bundel, blz. 25-57.

3) R. Cagnat, Cours d'Epigraphic latine, 3e éd., accompagnèe de planches et de figures, Par. 1898. 
aanteekeningen opeengehoopt, eerbied afdwingend voor den onvermoeiden j̈jver, de scherpzinnigheid en de geleerdheid van den schrijver. Maar niemand vermag deze ongeordende massa in het geheugen te bewaren. Men wordt niet in staat gesteld zich eene duidelijke roorstelling te scheppen van de hoofdzaken. Iets dergelijks moet gezegd worden van Le Blant's inscriptie-verzamelingen. Vóór de eerste verzameling heeft hij eene zeer lezenswaardige „preface" geplaatst (p. I-XLI); maar in het eigenlijke werk volgt ook hij de analytische methode. Doch Le Blant heeft meer gedaan dan dit. Reeds in het $j$. 1869 heeft hij een handboek der Christelijke opschriftenkunde ten beste gegeren ${ }^{1}$. Vijfentwintig jaar later heeft bij ongeveer dezelfde stof mogen behandelen in een eenigszins beknopter, bijna geheel nieuw werk ${ }^{2}$ ). Deze arbeid van Le Blant is voortreffelijk en kan zeer goede diensten bewijzen. Maar het valt te betreuren, dat hij zich beperkt heeft tot de gedenkstukken die op Franschen bodem gevonden zijn. Zoowel Le Blant als De Rossi (die zich voornamelïk tot de opschriften van Rome bepaalt) zijn in dit opzicht onvolledig. Er bestaat dringende behoefte aan een werk dat in systematischen vorm alle opschriften van Italië, Frankrijk en de Rijnstreek te zamen behandelt. Deze reden zou op zich zelf reeds voldoende zän oun nog een ander leerboek dan dat van Le Blant te verlangen ${ }^{3}$ ). Doch er is ook eene tweede reden. De Rossi en Le Blant zän beiden Roomsch-Katholiek geweest. Hoeveel eerbied ons ook voege voor hunnen ernstigen weten-

1). Edm. Le Blant, Manuel d'épigraphie chrétienne d'après les marbres de la Gaule, Par. 1869.

2) Edm. Le Blant, L'épigraphie chrétienne en Gaule et dans l'A frique romaine, Par. 1890 (in de Instructions adressées par le comité des travaux historiques aux correspondants du ministère de l'instruction publique).

3) Een goede schooluitgave is de volgende: Lateinische christliche Inschriften mit einem Anhang jüdischer Inschriften ausgewählt von E. Diehl, Bonn, 1908, in de Kleine Texte für theologische Vorlesungen, herausg. von Lietzmann. Een toelichtende tekst ontbreekt bier echter geheel. 
schappelijken zin, naast hunnen degelijken arbeid zou men soms ook de voorlichting van een Protestantschen geleerde begeeren.

De nieuwste werken op dit gebied zijn die van pater Syxtus ${ }^{1}$ ) en van Marucchi ${ }^{2}$ ). Het werk van Syxtus is een voortreffelijk leerboek voor studenten. Het geeft een zorgvuldig bearbeide stelselmatige behandeling van de stof. Vele bij den tekst passende voorbeelden in lichtdruk en in transscriptie zijn er in opgenomen. Zoolang er geen ander is, kan het aan velen goede diensten bewijzen. Maar het berust geheel op de werken van $D_{\theta}$ Rossi en Le Blant, en wordt gedrukt door dezelfde bezwaren als deze. Het elementaire handboekje van Marucchi is niet zonder verdienste. Als middel om de kennis van deze stof te verbreiden, kan het gewaardeerd worden. Maar het bepaalt zich enkel tot Rome. Het vult geenszins aan wat wij in De Rossi en Le Blant missen.

Het dient overigens erkend te worden, dat de manier van arbeiden, zoowel van De Rossi als van Le Blant, voortreffelijk is, in meer dan 6en opzicht vertrouwen verdient, en vele schoone, blïvende resultaten heeft opgeleverd.

Bijv. in de schifting van heidensche en Christelijke opschriften tasten zij niet mis. Een groot aantal grafschriften bestaan er, van welke met zekerheid mag worden aangenomen, dat zij van Christelïke herkomst zijn. Van minstens een even groot aantal is de heidensche oorsprong ontwöfelbaar. Daartusschen in worden er een zeer groote menigte aangetroffen, waarvan de herkomst onzeker is. De Rossi en Le Blant zijn zich hiervan volkomen duidelijk bewust, verzuimen niet het vóór en tegen te overwegen, en geven rekenschap van de gronden waarom aan eenig grafschrift

1) Syztus, O. C. R., Epigraphia, Romae, 1909 (in de Notiones archaeologicas christianae, Vol. II, P. I).

2) O. Marucchi, Epigrafia cristiana, trattato elementare, con una silloge di iscrizioni cristiane principalmento di Roma, Milano, 1910 (in de Manuali Hoepli). 
hetzij een Christelijke, hetzij een heidensche oorsprong moet worden toegekend.

Veel wordt in dezen afgeleid - en met recht - uit de plaats waar de grafschriften gevonden zijn. De inrichting van het graf en de wijze van begraven zijn bij heidenen en Christenen toch zoo verschillend, dat men zich hierin niet vergissen kan. Sierlïke grafmonumenten van heidenschen oorsprong zijn er in vrï grooten getale bewaard gebleven; bij de Christenen behooren zij tot de spaarzame uitzonderingen 1). Eigenlijk gezegd begraven kont bij de heidenen ternauwernood voor; maar zij verbranden het stoffelijke overschot hunner dooden, en verschaffen eene eerlijke bijzetting aan de urn waarin de asch bewaard wordt. Zij laten nu aan openbare wegen fraaie grafteekenen verrijzen; binnen ieder grafteeken bevindt zich een kelder, met nissen voor het bijzetten van een of meer urnen. Dikwịls zijn deze monumenten meters hoog, breed en diep; soms hebben zï den rorm van een tempeltje, of zijn zij met fraai beeldhouwwerk versierd. Men denke aan de schoone gedenkteekenen der Gravenstraat te Pompeji 2) of het reuzen-graf van Cecilia Metella op de Via Appia bij Rome ${ }^{3}$ ). Het begraven van de onverbrande lichamen der afgestorvenen kwam slechts bij uitzondering voor. Een voorbeeld vormen de graven der Scipionen dichter bij de stad. In diezelfde omgeving, nl. in een tuin langs den weg, de Vigna Codini, bevindt zich nog een oud "columbarium". Het is een ruime diepe kelder met als het ware rekken in baksteen boven elkander. In de ronde openingen dier rekken hangen kleine urnen. Soms is er in de kleine ruimte boven de opening een klein steenen kistje ingeschoven. Voor de urnen zĭn bordjes met een

1) Vgl. Le Blant, L'épigraphie chrétienne, p. 6.

2) 0.a. afgebeeld door Mazois, Les ruines de Pompéi, 1e Partie, Pl. I-XXXVIII.

3) Afb. bij Kaemmel, Rom und die Campagna, Bielef. 1902, S.111; Fraaie gravure bij J. Sponins, Miscellanea ervditae antiquitatis, Lrgd. 1685, fol., p. 287. 
naam aangebracht. Sedert eeuwen rust hier de asch ran honderden vrijgelatenen en slaven uit den eersten keizertijd ${ }^{1}$ ). Hoe geheel anders zijn de begraafplaatsen der Christenen, voornamelijk die in de katakomben te Rome. In de "loculi", uitgehouwen in de gangen en kamertjes, wordt het volledige stoffelijke overschot der dooden voor de Opstanding bewaard.

Doch behalve naar de plaats waar de opschriften gevonden worden, oordeelt men naar den inhoud daarvan, of men te doen heeft met heidensche of Christelijke. Er zïn uitdrukkingen die wel op heidensche maar niet op Christelijke graven voorkomen en omgekeerd. Op menig heidensch graf staat aangewezen hoeveel roeten in de lengte en breedte zich de heilige grond uitstrekt, in dezen vorm: In fr(onte) p(edes) $X X X V$, in ag(ro) p(edes) XXXX ${ }^{2}$ ). Waar degene die het monument heeft opgericht zich zelf priesteres van Ceres noemt ${ }^{3}$ ), is de heidensche oorsprong overduidelijk. Ook de vermelding $\operatorname{van}$ de opeenvolgende waardigheden op militair en staatkundig gebied, die de orerledene heeft bekleed "), stempelt een graf tot een heidensch graf. Hetzelfde doet de rermelding van de personen wier stoffelijk overschot in het grafmonument rusten mag. Zoo verklaart Naevoleia Tyche, dat haar monument bestemd is voor hasr zelf, haren man en voor beider mannelijke en vrouwelïke vrijgelatenen ${ }^{5}$ ). Ook worden soms personen uitdrukkelïk buitengesloten : $(\mathrm{h}[\mathrm{oc}] \mathrm{m}$ [onumentum] $\mathrm{h}$ [eredes] $\mathrm{n}$ [on] s[equitur]) $\left.{ }^{6}\right)$. De onderscheiding

1) Afb. bij Kaemmel, S. 109.

2) Zie het grafschrift bij Kraus, Roma sotterranea, Freib. i. B. 1879, S. 77 ; dat bij Mazois, Les ruines de Pompei, Ie Partie, Voie, Tombeaux, Pl. VII, fig. 3 ; Ae. Hübner, Exempla scriptvrae epigraphicae, Berol. 1885, fol., num. 4, p. 5 (Corpus Inscriptionum latinarum, Berol. 1882, T. VI, P. II, nr. 1226!, p. 1526).

3) Grafteeken van M. Alleius Luccius Libella te Pompeji, bij Mazois, 1. c., T. I, Pl. XVII, fig. 1.

4) Hetzelfde grafteeken bij Mazois, PI. XVII ; Cagnat, Cours d'Epigraphie latine, Ch. II, cursus honorum, p. 86-153.

5) Bij Mazois, 1. c., Ie Partie, PI. XXI, fig. 2 ; vgl. bij Hübner, nr. 463, p. 156 (C I L VIII 5280: se vivo sibi posterisque suis).

6) Bij Hūbner, num. 8, p. 6 (Henzen, Inscriptionum latinarum 
van levenden en dooden door de teekens $\nabla$ (vivus, vivit) en $\Theta$ (obitus, obiit) ${ }^{1}$ ) komt alleen op heidensche grafschriften voor ${ }^{2}$ ). Inzonderbeid het veelvuldig voorkomende $D$ (is) $M$ (anibus) wijst op den heidenschen oorsprong ${ }^{3}$ ).

Hetzelfde dient gezegd van de vermelding dat de oprichting van het monument geschiedt krachtens eene uiterste wilsbeschikking ${ }^{4}$ ). Ook zekere verwenschingen tegen degenen die het mochten wagen de rustplaats der dooden te schenden zïn eigen aan heidensche graven, bijv. het $\mathrm{H}$ (uic) $\mathrm{M}$ (onumento) $\mathrm{D}$ (olus) $\mathrm{M}$ (alus) $\mathrm{A}$ (besto) ${ }^{5}$ ).

Onderscheidene Christelijke grafschriften vertoonen in de bewoordingen eene opmerkelijke overeenkomst met heidensche. Le Blant beschouwt dit als eene aanwïzing van hoogen ouderdom ${ }^{6}$ ). Eene vermelding van de dagteekening door het cïfer der indictie wordt wel op Christelijke, maar niet op beidendsche grafschriften aangetroffen 7 ). Eene nauwkeurige opgave van den dag waarop de ge-

amplissima collectio, volumen tertium, Turici, 1856, nr. 6457, p. 288); Hübner, nr. 99, p. 31 (C I L, VI, P. II, 9438, p. 1240).

1) Cagnat, 1. c., p. 256.

2) Bij Hübner, nr. 36, p. 12 (Herzog, Gallia Narbonensis, Lips. 1864, Appendix epigraphica, p. 58, nr. 281); bij Hūbner, nr. 90, p. 31 ; nr. 376, p. 128 (C I L II 9438 en III, (Berol. 1873), 5567).

3) Bij Hübner, nr. 292, p. 98 ; nr. 296, p. 99 ; nr. 309 , p. 103 ; nr. 358 , p. 121 ; nr. 377 , p. 128 ; nr. 385 , p. 133 ; nr. 393 , p. 135 ; nr. 449 , p. 153 ; nr. 493 , p. 167 ; nr. 540 , p. 183 ; nr. 738 , p. 251 (C I L VI, P. I $(1876), 2896$, p. 732 ; 1387 , p. 304 ; P. II, 1882, 14672, p. 1711; V, P. II, (Berol. 1877), 7107, p. 798 ; III, P. I, Berol. 1873, 3685, p. 463 ; XII, (Berol. 1888), 755, p. 102; Spon, Recherche des antiquités de Lyon, ed. Monfalcon, Lyon, 1857, p. 368); C I L VIII, 1026 ; VI, P. I, Berol. 1876,3495 , p. 809 ; 1779 a, p. 397 . Vgl. C. Bone, Anleitung zum Lesen, Ergänzen und Datiren römischer Inschriften, Trier, 1881, S. $20 \mathrm{f}$.

4) Bij Hübner, nr. 10, p. 7 (C I L X, Berol. 1882, 3758, p. 363: ex testamento); nr. 386, p. 133 (Dictionnaire archélogique de la Gaule, époque celtique, I, p. 173: ex testamento poni iussit).

5) $\mathrm{Bij}$ Hübner, nr. 309, p. 103 (C I L VI, P. II, 14672, p. 1711); vgl. Cagnat, p. 253. Vgl. echter Le Blant, L'épigraphie chrétienne, p. 54 en het daar besproken grafschrift uit Bosio, Roma sotterranea, p. 436: Male pereat insepultus iaceat non resurgat cum Iuda partem habeat si quis sepulcrum hunc violaverit.

6) Le Blant, L'épigraphie, p. 10 en de opschriften op p. 11 (Pl. I).

7) Le Blant, l.c., p. 6. 
storvene het tijdelijke met het eeuwige heeft rerwisseld, in Christelijke grafschriften zeer gewoon 1), wordt in de heidensche volstrekt vermeden. Dit hangt natuurlijk samen met de verschillende beschnuwing van den dood. De heidenen beschouwden het sterven als een noodlottige ramp, waaraan zij niet begeerden herinnerd te worden; de Christenen als den overgang naar een nieuw leven. Het uitspreken van de troostrijke verwachting van het hiernamaals vormt dan ook een duidelijk onderscheidend kenmerk van Christelijke grafschriften. Men verzekerde van de dooden, dat $z$ ij transierunt ad veram remean(te)s e corpore vitam"; men uitte zijn geloof dat de jongedochter die vromelijk geleefd had en gestorven was "beatior in domino condidit mentem" 2).

Een tweede gebied, waarop $D_{\theta}$ Rossi en Le Blant vruchtbaren arbeid verricht hebben, is de vaststelling van de dagteekening der inscripties. Deze dagteekening wordt meestal aangegeren door de namen der consuls. De jaarlïsten dezer consuls nu, de „fasti consulares”, zijn van oudsher bekend, en ook in druk uitgegeven ${ }^{3}$ ). Het talent, waarmede $\mathrm{De}$ Rossi en Le Blant de dikwijls eenigszins onduidelijke opgaven tot klaarheid hebben gebracht en fragmentarische opschriften op afgebrokkelde steenen of marmeren platen aangevuld, verdient oprechte bewondering.

1) Zie bij De Rossi, Inscriptiones, T. I, nr. 6, p. 10 (X Kal. Aug.);

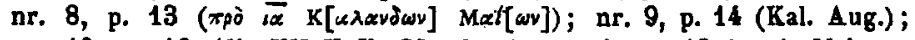
nr. 10, p. 16 (die XII Ka[l, O]ctobres); nr. 11. p. 18 (nonis Nobembribus, die Beneres); nr. 12, p. 19 (XIII Kal. Febr.); nr. 13, p. 20 ; nr. 47, p. 42 ; nr. 59 , p. 47.

2) Le Blant, L'épigraphie, p. 8 en PI. III.

3) On. Panvinius, Fastorum $l l$. $V$ a Romulo rege usque ad Imp. Caes. Carolum $V$; jusdem in Fastorum ll. commentarii, Venet. 1558, fol.; dezelfde, Commentariorum in Fastos consulares appendix, Venet. 1558, tol.; J. Blein, Fasti consulares inde a Caesaris nece usque ad imperium Dioiletiani, Lips. 1881. De Fasti consulares capitolini rec. J. C. M. Laurent, Altonae, 1833, loopen niet verder dan tot het begin onzer jaartelling. Eene uitmuntende schooluitgave: Fasti consulares imperii romani von 30 v. Chr. bis $565 \mathrm{n}$. Chr., mit Kaiserliste, bearb. v. W. Liebenam, Bonn, 1910 (in de Kleine Texts für theologische. Vorlesungen van H, Lietzmann). 
De kennis van de dagteekening der inscripties levert de gewichtigste voordeelen op. Allereerst geldt dit voor de bestudeering der muurschilderingen in de katakomben. Men kan zeggen, dat De Rossi zïn "Roma sotterranea” nooit had kunnen schrïjen.als niet zijne "Inscriptiones" voorafgegaan waren. De laatste vormden den hechten grondslag voor het eerste. De studie der muurschilderingen begon eerst onbetwistbare resultaten op te leveren, sedert zij gerangschikt konden worden naar den tijd van haar ontstaan. Dit werd mogelijk door de ontcïfering der opschriften, die zich in de gangen en de cubicula der katakomben in hare onmiddellijke nabijheid bevinden. Van menige muurschildering staat sedert dien genoegzaam vast, dat zij kort roor of kort na een bepaald jaartal aangebracht zal zijn. Bevindt zij zich in zekeren gang dieper naar achter dan een gedagteekend opschrift, dan mag zij later, of meer naar voren, dan mag zij rroeger gesteld worden. Wordt zij een verdieping lager aangetroffen dan gedagteekende inscripties, dan mag met stelligheid een latere tijd van ontstaan worden aangenomen. De Rossi in zijn "Roma sotterranea" en Wilpert in zijne "Wandmalereien" hebben van dit criterium een goed gebruik gemaakt.

Er zijn ook andere uitkomsten die uit de kennis van de dagteekening der inscripties voortvloeien. Zoo weten wij hierdoor, dat zeer beknopte grafschriften' gewoonlijk van zeer hoogen ouderdom zijn. Zoo is het korte „Vera in pace" waarschijnlijk zeer oud ${ }^{1}$ ). . Op beidensche opschriften is het bijna regel, dat vermeldt wordt wie het grafmonument heeft opgericht. Komt zoodanige vermelding op eene Christelijke inscriptie voor, dan kan zij gelden als een bewijs van ouderdom ${ }^{2}$ ), daar men haar in ver-

1) Zie Le Blant, L'Epigraphie, p. 10 en Pl. II ; vergel. Roller, Les catacombes de Rome, PI. XX, nr. 1; Pl. XXII, nr.4,11-14; Le Blant, Les sarcophages d'Arles, Introduction, p. 4.

2) $\mathrm{Bij}$ De Rossi, Inscriptiones, T. I, nr. 6, p. 10 (uit 234); nr. 10, p. 16 (uit 268 of 279 ); nr. 11, p. 18 (uit 269); nr. 15, p. 22 (uit 290); bij Roller, Les catacombes de Rome, T. I, PI. X, nr. 5, 6, 9, 10, 22, 27; Pl. XXI, nr. 9; Pl. XXII, nr. 6. 
loop $\tan$ jaren allengs in onbruik ziet geraken ${ }^{t}$ ). Alleen in de oudste inscripties komen personen voor met drie namen, praenomen, nomen en cognomen, zooals de Romeinen droegen in den besten tijd. Christelijke inscripties van dien aard zijn er trouwens - maar zeer weinig bewaard gebleven. Later ziet men personen opkomen met twee namen en weder later met slechts een enkelen naam 2). Merkwaardige uitkomsten heeft $L_{\theta}$ Blant door de studie van de dagteekening der opschriften verkregen roor de kennis van den tijd, waarin zekere symbolische figuren optreden. Hij heeft hiervan eene beknopte lijst opgesteld ${ }^{3}$ ). Het anker schijnt de oudste symbolische figuur te zijn. De visch heeft Le Blant op Franschen bodem slechts ontmoet op inscripties van 471,631 en later ${ }^{4}$ ). Het monogram ${ }_{3}$ trof hij aan op Fransche inscripties van 347 tot $493^{5}$ ). De $A$ en $\Omega$ van 377 tot $547^{\circ}$ ); de duif van 378 tot 612 7); het vereenvoudigde monogram $P$ van ongeveer 400 tot 525 of $540^{8}$ ). Een eenvoudig kruis $t$, voor den eersten regel van een groot opschrift ter gedachtenis van een kerkbouw voorkomende in $445^{9}$ ), wordt op een grafschrift het eerst gezien in $448^{10}$ ), aan bet begin van den eersten regel van een grafschrift pas in $503^{11}$ ). Eev vaas wordt op de grafschriften van Frankrijk het eerst afgebeeld in $450^{12}$ ).

Ook voor de symbolische figuren op de graven der

1) Le Blant, L'Epigraphie, p. 7.

2) Le Blant, L'épigraphie, p. 23.

3) Le Blant, L'épigraphie, p. 22.

4) Le Blant, l.c., p. 21.

5) Le Blant, Inscriptions chrétiennes de la Gaule, nr. 596, T. II, p. 416; nr. 77, T. I, p. 160.

6) Le Blant, lbidem, ar. 369, T. I, p. 496 ; nr. 467, T. II, p. 160.

7) Le Blant, Ibidem, nr. 7, T. I, p. 19 s.; nr. 561, T. II, p. 330.

8) Le Blant, Ibidem, nr. 412, T. II, p. 62 ; nr. 55, T. I, p. 115.

9) Le Blant, Ibidem, nr. 617, T. II, p. 466.

10) Le Blant, Ibidem, nr. 68, T. I, p. 150.

11) Le Blant, Ibidem, nr, 70, T. I, p. 152.

12) Lo Blant, Ibidem, nr. B15, T. II, p. 252. 
Christenen te Rome 1) moeten deze cijfers zekere beteekenis hebben, al mag men aannemen, dat dezelfde figuren in den regel iets vroeger te Rome zullen zijn voorgekomen dan in Frankrijk.

De weg, waarlangs het Christendom in Frankrijk is doorgedrongen, wordt al mede door de gedagteekende inscripties opgehelderd. De meening van sommigen, dat het evangelie reeds in de. eerste eeuw verkondigd zou zijn in geheel Gallië, wordt door niets berestigd; oude opschriften worden alleen aangetroffen in de streek van de Rhône, de oudste het dichtst bij de Middellandsche ze日 ${ }^{2}$ ).

Hoogst leerzaam is het aan de inscripties te zien, welk eene groote plaats het geloof in de lichamelijke opstanding heeft bekleed in de verwachtingen der oude Christenen. De heidenen denken bij het graf hunner dierbaren vooral aan het scheiden voor altijd, aan het laatste vaarwel, dat ook soms in beeldhouwwerk aanschouwelijk wordt gemaakt ${ }^{3}$ ). Zij drukken de hoop uit, dat de doode de eeuwige rust moge zijn ingegaan "). Overigens uiten zï voornamelijk diepe smart en rouw, of troostelooze onderworpenheid ${ }^{5}$ ). De verwachting van een leven na dit leven is aan sommigen niet vreemd; doch in de meeste gevallen is de voorstelling die zij er van koesteren die van voortbestaan in het schimmenrïk. B̈̈ vitzondering hoopt men op een gelukkig lot in de Elizeesche velden, op het eiland der gelukzaligen, waar de goden en de heroën wonen $\left.{ }^{6}\right)$. Eerst bij de Christenen, voor wie de wederopstanding des vleesches een voornaam geloofsartikel uitmaakt, komt deze verwachting tot hare volle ontplooiing. De overlerenden

1) Zie de afbeeldingen daarvan bij Roller, Les catocombes de Rome, T. I, Pl. $X$ en $X I$.

2) Le Blant, L'épigraphie, p. 41.

3) C. M. Kaufmann, Die sepulcralen Jenseitsdenkmaler der Antike, Taf. 2.

4) Bij Hübner, Exempla scriptorae epigraphicae latinae, nr. 393, p. 135 ; C. M. Kaufmann, Die Jenseitshoffnungen der Griechen und Römer nach den Sepulcralinschriften, Freib., i. B., 1897, S. 41.

5) Bij Kaufmann, Jensei tshoffnungen, S. 40,42, 44, 49, 53, 54, en passim.

6) Bij Kaufmann, Jonseitshoffinungen, S. 45. 
drukken voor den dierbaren afgestorvene den wensch uit:

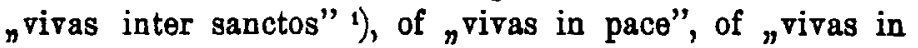

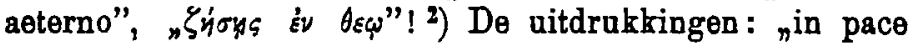
spiritus", "spiritus in irene", "spiritus in bono" behooren tot denzelfden gedacbtenkring ${ }^{3}$ ), zoo ook de stellige verzekeringen: "Jobina recessit a seculo, ingressa in pace" en het "Aquilina dormit in pace" "). Sprekend zïn ook de ontboezemingen: "leef in God", of "leef in den Heer", of "leef met de engelen"; niet minder: "de vrede van God en Christus zij met Faustino Attico", of "leef in den geest", of "de Heer zij met uwen geest" 5). Niet ge makkelijk te verklaren zijn uitdrukkingen als deze: „in refrigerio", of „anima dulcis in refrigerio", of „refrigeretis" "), maar dat zij betrekking hebben op het hiernamaals is duidelijk. Treffend wordt van de afgestorvenen verzekerd, dat $z i j$ den dood verloren hebben en het leven gevonden ${ }^{7}$, , of dat zij uit het lichaam terugkeerende overgegaan zijn tot het ware leven ${ }^{8}$ ). En het grafschrift van Leucadia, "het meisje dat aan God gewijd was", verklaart, dat zij haar leven heeft volbracht zooals zij zich had roorgenomen en daarna in zaligen toestand hare ziel aan God heeft overgegeven ${ }^{9}$ ). Uitroerig worden de verwachtingen die

1) Bij De Rossi, Inscriptiones, T. I, nr. 10 (uit 268 of 279).

2) Bij Roller, Les catacombes, T. I, P). XXXII, nr. 10, 9, 2; ook XXXIII, nr. 2.

3) Bij Roller, 1. c., Pl. XXXII, nr. 11, 12, 13.

4) Ib., nr. 4, 8.

5) Bij Roller, PI. XXXIII, nr. 6: "vives in Deo"; nr. 7: „vivas in

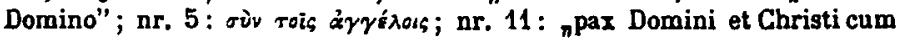
Faustino Attico"; nr. 12 : "vivas in spiritu"; nr. 9: "Deus cum spiritu tuo". Barbaarsche woordvormen zijn hier stilzwijgend in gewone omgezet.

6) Bij Roller, Pl. XXXIII, nr. 16: „Niceforus anima dulcis in refrigerio;

nr. 17: Ursus Alexander et Valerus in refrigerio"; verder op p. 221 : „C. Vivio Alexandro Talisie Pompeie refrigeretis".

7) Bij Le Blant, Nonveau recueil des inscriptions de la Gaule, nr. 130 , p. 149 : mortem perdidit, vitam invenit.

8) Bij Le Blant, Inscriptions chretionnes de la Gaule, nr. 380, T. II, p. 18.

y) Bij Le Blant, L'épigraphie, p. 85 en Pl. III: ${ }_{n}^{\text {beatior in Domino }}$ condedit mentem". Vergel. het grafschrift ran Septimius Praetertatus,

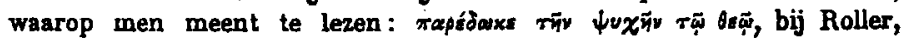
Catacombes, T. I, PL. XXII, nr. 10. 
men koesterde omtrent het hiernamaals uitgesproken in een tweetal grafschriften, gevonden kort voordat De Rossi het eerste deel zijner "Inscriptiones" voltooide. Het eene luidt: "Hier ligt het lichaam van de bij God zeer beminde Julia Euaresta; doch bare ziel, vernieuwd door den geest van Christus en een hemelsch lichaam aangenomen hebbende, is opgenomen in Christus' bemelsche koninkrijk met de heiligen". Het andere, uit den tijd van Marcellinus, bisschop van Rome (295-304), vermeldde eerst, dat diaken Severus een dubbel "cubiculum" heeft laten aanleggen voor zich en de zijnen; dan vereeuwigt hij den dood zijner dochter Severa op de volgende wijze:

Serera dulcis parentibus et famulisque

Reddidit octarum Febrarias virgo kalendas.

Quam Dom(inu)s nasci mira sapientia et arte

Jusserat in carnem; quod corpus pace quietum

Hic est sepultum, donec resurgat ab ipso.

Quique animam rapuit spiritu sancto suo

Castam pudicam et inviolabile(m) semper

Quamque iterum Dom(inu)s spiritali gloria reddet.

Quae vixit annos novem et undecim menses,

Quindecim quoque dies: sic est translata de saeclo ${ }^{1}$ ).

Door het bovenstannde wordt duidelijk, dat de studie der oud-Christelijke opschriften reeds belangrïke uitkomsten van duurzamen aard heeft opgeleverd. Doch nog reel blijft er te doen over. Moeilijke vragen bestaan er, waarop het gewenscht zou zijn een bevredigend antwoord te bezitten. Met volkomen erkenning van de verdiensten van De Rossi en Le Blant zou men kunnen verlangen, dat meer dan gon gedeelte der stof ook door een Protestantsch onderzoeker werd behandeld, om te bezien of zijne uitkomsten met die van De Rossi en Le Blant overeenstemden. Op hunne grondigheid, hunne goede trouw en wetenschappelijken zin behoeft niets te worden afgedongen. Maar het was niet gebeel te vermijden dat zij

1) De Rossi, Inecriptiones, prolegomena, p. CXV seq.

XI. 
sommige vraagstukten bezagen uit hun eigen oogpunt. Misschien zou iemand die uit eene Protestantsche school was voortgekomen en dezelfde vraagstukken uit zijn oogpunt beschouwde, hier of daar een afwïkend resultaat verkregen hebben. Om slechts enkele dingen te noemen: de beteekenis der drie eerste inscripties van De Rossi staat niet genoegzaam vast. Als de eerste inderdaad ran Christelijken oorsprong is, bewijst zij, dat er in het $j .70$ al Christenen te Rome waren en dat zï eene onderaardsche begraafplaats bezaten. Doch juist deze Christelïke-oorsprong, door De Rossi zeer waarschijnlijk geacht ${ }^{1}$ ), is betwistbaar ${ }^{2}$ ). Is de tweede inscriptie bij de Rossi wel een grafschrift? Haar vorm is zoo zonderling dat er, volgens De Rossi zelven, onder de duizenden Christelïke opschriften slechts 6 ón is die er op gelïkt ${ }^{3}$, nl. die welke hij onder nr. 4 behandelt $\left.{ }^{\star}\right)$, en waaromtrent misschien dezelfde vraag gedaan zou kunnen worden. Staat de oorsprong van $\mathrm{De}$ Rossi's derde inscriptie $\nabla a s t$ ? Boldetti heet haar in de katakombe van Lucina gevonden te hebben. Nu zegt $\mathrm{De}$ Rossi, dat de ouderdom van het opschrift - het is uit 111 - wel overeenstemt met hetgeen wij weten omtrent die katakombe. Immers is (rolgens $D e$ Rossi) de apostel Paulus daarin begraven en heeft Boldetti er ook het vorige opschrift (uit 107) in aangetroffen 5). Is deze bewïsroering wel heel klemmend? Men moge geneigd zijn met De Rossi mede te gaan, men zou toch een vasteren grond onder de voeten kunnen verlangen.

Volgens Dio Cassius heeft keizer Domitianus zïnen neef, den consul Flavius Clemens, laten ter dood brengen, en diens vrouw, Flavia Domitilla, ereneens zijne verwante, verbannen naar het eiland Pandataria ${ }^{6}$ ). Zij waren

1) De Rossi, Inscriptiones, T. I., p. 3.

2) Kraus, Roma sotterranca, S. 70, Anm. 1.

3) De Rossi, Inscriptiones, nr. 2, p. 3.

4) Ibidem, p. 8.

5) Ibidem, p. 7.

6) Dio Cassius, Bistoria Romana, ed. H. S. Reimarus, Hamb. 1752, Vol. II, L. LXVUI, \$ 13. 


\section{9}

beschuldigd van atheïsme en van het rolgen van Joodsche gebruiken en inzettingen; waarschijnlijk slaat dit op het aanhangen van den Christelïken godsdienst. Eusebius bericht, dat volgens oude niet-Christelijke schrijvers Domitianus in het vijftiende jaar zijner regeering met vele anderen ook eene Flavia Domitilla, de dochter eener zuster van den toenmaligen consul Flavius Clemens, om het belijden van Christus naar het eiland Pontia heeft verbannen $\left.{ }^{1}\right)$. Ook Hiëronymus toont van eene naar Puntia verbannen Flavia Domitilla te weten, zonder dat hij echter hare af komst nauwkeurig aangeeft. $\mathrm{H} i \mathrm{j}$ verzekert slechts, dat de $\mathrm{H}$. Paula op hare reis naar Jeruzalem het eiland Pontia, het verbanningsoord dezer Flavia Domitilla, heeft bezocht ${ }^{2}$ ). Is hier sprake van eene en dezelfde persoon of van twee? De Rossi heeft met groote scherpzinnigheid een geslachtsboom van de familie der Flaviërs, waartoe de keizers Vespasianus, Titus en Domitianus behoorden, opgesteld ${ }^{3}$ ). Hierin komen twe vrouwen met den naam Flavia Domitilla voor, de eene de echtgenoot, de andere de nicht van den consul Flavius Clemens. De berichten van Dio Cassius en Eusebius zouden dus beide juist kunnen zïn, als men aanneemt dat Domitianus twe malen eene Flavia Domitilla verbannen heeft. Hoe dit zij, er bestaat genoegzaam grond om aan te nemen, dat alras een vrouwelijk lid der keizerlijke familie tot de Christenen heeft behoord. Van oudsher is er eene katakombe geweest waaraan de naam van Domitilla verbonden was. Het gelukte De Rossi deze katakombe nauwkeurig terug to vinden. In 1817 was in een tuin aan de Via Ardeatina, anderbalve mijl van de stad, en thans nog bekend onder den naam van Tor Marancia, een heidensch grafschrift aangetroffen. Het vermeldt, dat

1) Eusebius, Historia ecclesiastica, L. III, c. 18.

2) Hieronymus, $A d$ Eustochium virginem epitaphium Paulae matris, in zijne Opera omnia, per Des. Erasmvm em., Par. 1546, T. I, fol. 58", col. $2 l$; in de Itinera Hierosolymitana, edd. T. Tobler en A. Molinier, Gen. 1880, T. I, p. 30.

3) De Rossi in het Bullettino di archeologia cristiana, van 1865, p. 21; daarnaar bij Kraus, Roma sotterranea, S. 42. 
de grond voor het graf een geschenk is van Flavia Domitilla ${ }^{2}$. In 1772 bezat iemand een "epitaphium", in dezelfde omgeving gevonden, waarop men de woorden las: "Flariae Domitil(lae divi) Vespasiani neptis .... beneficio"z). $\mathrm{Nu}$ houden de Akten der H.H. Achilles en Nereus trouwens een stuk van twïfelachtige echtheid - in, dat deze twee, die kamerdienaren van de als Christin verbannene Flavia Domitilla geweest waren, met het zwaard gedood en begraven zijn in een katakombe, gelegen in een tuin, die aan hunne meesteres toebehoörde, op de Via Ardeatina, anderhalve mijl van de stad. Op dit alles werd een verrassend nieuw licht geworpen door opgravingen in de jaren 1865 en 1874 op dit terrein geschied. Dicht aan de oppervlakte trof men een gebouw aan, dat kennelijk gediend had als begraafplaats voor een hoogst aanzienlijke Romeinsche familie. Naderhand werden belangrïke overblijfselen blootgelegd van eene kleine basilica. Onder brokstukken van opschriften die in het puin verstrooid lagen, vond men er een, dat aan de sierlijke letters erkend werd als een fragment van een der opschriften van paus Damasus, behelzende eene lofspraak op de martelaren Nereus en Achilles. De inscriptio was reeds rroeger afgeschreven en opgenomen in de rerzameling van Gruterus, onder nr. 1171b. Het viel De Rossi licht de overgebleven woorden op den gebroken steen aan te vullen uit den gedrukten tekst. Nog werd een stuk gevonden van een kolom, die gediend kan hebben om het altaar te schragen. In relief staat er eene onthoofding op afgebeeld en daarboven wordt de naam: Acilleus gelezen. Men was dus wel in de katakombe van Domitilla. Ten laatste werd in het bovenbedoelde bouw werk, waarin aanzienlijke Romeinen begraven moeten zijn, een opschrift met de namen van Flaviërs gevonden. Het luidt:

1) Bij De Rossi, Roma sotterranea, T. I, p. 267 ; daarnaar bij Kraus, S. 77.

2) De Rossi, Bullettino di archeologia christiana, 1865, p. 23; bij Kraus, S. 77. 


\section{$\cdot \Phi \Lambda \cdot$ CABEINOC* KAI·}

'TITIANH' A $\triangle \mathrm{E} \Lambda \Phi O \mathrm{OI}^{1}$ ).

Dezen steen had Marangoni in 1741 gezien; daarenboven een ander in de onmiddelljke nabijheid met de woorden:

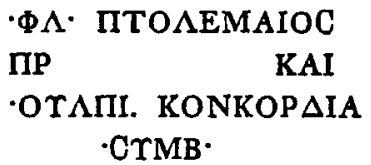

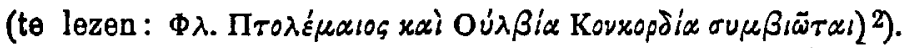

Op grond van het een en ander hebben $D_{e}$ Rossi en in zijn roetspoor Wilpert de gevolgtrekking durven maken, dat de besproken begraafplaats der Flaviërs nog dagteekent uit het einde der eerste eeuw $n$. Chr. Ook de muurschilderingen aldaar zullen nog uit dien tijd zijn ${ }^{3}$ ). Op soortgelijken grond is aangenomen, dat de voorstelling van het gesprek van Christus met de Samaritaansche vrouw op den wand in de katakombe van Praetextatus uit de eerste helft der $2^{\text {de }}$ eeuw afkomstig zal zijn ${ }^{4}$ ).

Als dit alles juist is, bezit het groote beteekenis. Men moet dan bijr. aan de vroegste Christelijke gemeente te Rome eene veel rasscher ontwikkeling toekennen dan onder Protestanten, inzonderheid $\mathrm{van}$ de historisch-kritische school, pleegt te worden aangenomen. Maar staat het in hoofdzaken en bïzonderheden rolkomen vast? Mocht men niet wenschen, dat dit alles opnieuw werd onderzocht, bijv. door een Protestantsch geleerde, geschoold in de historische kritiek?

Meer punten kunnen worden opgenoemd, waaromtrent nieuwe navorschingen gewenscht zouden zijn. Le Blant meent op grond van de inscripties te kunnen aantoonen, dat de Christenen van oudsher begeerd hebben in de kerk begraven te worden, liefst dicht bij het altaar, dicht

1) Gephotographeerd bij Roller, Les catacombes de Rome, T. I. PI. XII, nr. 10.

2) Zie Kraus, Boma sotterranea, S. 76-87, op grond van De Rossi's Bullettino van 1865, 1874, 1875.

3) Bij Wilpert, Wandmalercien, Freib, i. B., 1903, Tal. 2, 4, 5, 9, 11.

4) Bij Wilpert, Wandmalereien, Taf. 19. 
bij "de heiligen". Het eerste opschrift, dat hij tot staving hiervan bübrengt, nl. dat van zekeren Pantagathus, gevonden te Vaison, is echter eerst uit het. j. 515 1); en de andere zijn van nog later tijd ${ }^{2}$ ). Zou het niet de moeite waard zijn dit onderwerp nog eens opnieuw te behandelen?

Hebben de Christenen van den ouden tijd de heiligen aangeroepen? Elders heb ik, mede op grond van de inscripties, die rraag berestigend beantwoord ${ }^{3}$ ). Is echter de wïze waarop Le Blant dit onderwerp heeft bebandeld, berredigend? Men stelde, zegt hij, geheele steden onder de hoede van zekere heiligen. Hierbij beroept hij zich o. a. op een gegraveerden onyxsteen, die nog van later dagteekening is dan de 8 ste eeuw "). Verder verzekert hïj, dat men de bemiddeling der heiligen afsmeekte om te mogen ingaan in de hemelsche gewesten. Maar het eerste opschrift, waarnaar hij verwijst, is uit de $5^{\text {de }}$ of het begin der 6 de eeuw ${ }^{5}$ ); het tweede heeft geen tijdsbepaling ${ }^{6}$ ) (het spreekt trouwens wel van opstanding met de heiligen, maar niet van hunne aanroeping); het derde uit het einde der 6 de eeuw 7 . Andere kunnen evenmin als bet tweede als bewijs roor de aanroeping der heiligen dienen ${ }^{8}$ ). Ook hier blijft dus wel iets te rragen en te onderzoeken over.

Slotsom: met rolkomen erkenning van de groote en blj̈vende verdiensten van De Rossi en Le Blant, kan

1) Le Blant, Inscriptiones chrétiennes de la Gaule, nr. 492, T. II, p. 218 s., 229.

2) Le Blant, L'epigraphie, p. 32.

3) F. Pijper, De heiligenvereering, 's-Gravenh. 1911, blz. 23-26.

4) Le Blant, L'Epigraphie, p. 35; Nouveau recueil; Inscriptions chrétiennes de la Gaule, nr. 20, p. 24 s.

5) Le Blant, L'épigraphie, p. 36 ; Inscriptions chrétiennes de la Gaule, nr. 478, T. II, p. $198,201$.

6) Le Blant, L'épigraphie, p. 36 ; Inseriptions chrétiennes de la Gaule, nr. 419 , T. II, p. 81 .

7) Le Blant, Ibidem, nr. 708, T. II, p. 596.

8) Le Blant, Ibidem, nr. 610, T. II, p. 455. De inscriptio is uit het j. 455. Een priester verklaart, dat hij eene kerk gebouwd heeft: ${ }_{n}$ in honorem sanctorum martyrum Vincenti Agnetis et Eulaliae". 
worden vastgesteld, dat hier nog een ruim veld ter bearbeiding open ligt.

Wenschelïk zou zijn het scheppen van een nieuw leerboek der Christelijke epigraphie, dat zich zoove日l mogelijk uitstrekte over het geheele thans bekende en beschreven materiaal, niet enkel de inscripties op Italiaanschen, of niet enkel die op Franschen bodem behandelde, maar alle, waar ook geronden. En ter aanvulling (misschien verbetering) van hetgeen De Rossi en Le Blant in de opschriftenwereld hebben waargenomen - uit hún oogpunt, zou het zijn nut kunnen hebben dat de stof eens bezien werd uit een ander oogpunt, bijv. door een in de historischkritische school wel onderlegden Protestant.

Is hier misschien ook iets te verwachten van jonge Nederlandsche theologanten? Z jun er onder onze aankomende geleerden ook die de eervolle traditiën willen ophouden van Nederlanders, die zich vroeger op dit gebied verdienstelijk hebben gemaakt, ran Winghius, Pighius, Smetius en Gruterus?

Leiden. 